\title{
Modes and Forms of Knowledge of Farming Entrepreneurship: An Ethnographic Analysis among Small Farmers in NW Italy
}

\author{
Michele Filippo Fontefrancesco ${ }^{1,2}$ (D) \\ 1 University of Gastronomic Sciences, 12042 Bra, Italy; m.fontefrancesco@unisg.it \\ 2 Department of Anthropology, Durham University, Durham DH1 3LE, UK
}

check for updates

Citation: Fontefrancesco, M.F. Modes and Forms of Knowledge of Farming Entrepreneurship: An Ethnographic Analysis among Small Farmers in NW Italy. Knowledge 2021, 1, 2-11. https://doi.org/10.3390/ knowledge1010002

Academic Editor: Jose María Merigo

Received: 25 July 2021

Accepted: 3 September 2021

Published: 8 September 2021

Publisher's Note: MDPI stays neutral with regard to jurisdictional claims in published maps and institutional affiliations.

Copyright: (C) 2021 by the author. Licensee MDPI, Basel, Switzerland. This article is an open access article distributed under the terms and conditions of the Creative Commons Attribution (CC BY) license (https:// creativecommons.org/licenses/by/ $4.0 /)$.

\begin{abstract}
This article investigates the modes and forms of knowledge underpinning farming entrepreneurship through an ethnographic case study of Alessandria province in NW Italy. It shows that farming entrepreneurs base their decisions on explicit and implicit knowledge encompassing forms of knowledge linked to the environment where they live, their trade, the characteristics of their firms, issues concerning their family and private life, and even the emotions linked with their surroundings. All these forms of knowledge inform their vision of their future and guide them in their choices in terms of investments and crop selection. Accordingly, the article argues that farming entrepreneurship is embedded in the locale.
\end{abstract}

Keywords: rural development; entrepreneurship; economic anthropology; ethnography; Italy

\section{Introduction}

The golden wheat ears stand out on the horizon. On the first warm days of summer, the sky has the same color as sugar paper. In a few days, on the day of St John, the field will be cut, and the new wheat will begin its journey to the mills and processing companies. In front of me, several tens of hectares retell the story of Monferrato, a land to the north of the Apennines in the centre of NW Italy. The grapes in the surrounding vineyards are still green but will be ready for the harvest in three months; at more or less the same time, the fruit of the hazelnut trees that have started to cover a large part of the territory will mature.

This landscape in its materiality represents the last chapter of a story still to be completed, one that began over 12,000 years ago on the banks of the Tigris and Euphrates. Since then, Italy has developed its agricultural history, deeply rooted in grain and wheat production as well as wine [1-3]. This long history produced the landscape that we can enjoy today.

Indeed, the rural countryside is the result of relentless anthropic action, carried out by men and machinery and shaped by the agricultural choices made by farmers of small and big farms every day. In this respect, agriculture represents a privileged field of exploration for understanding the interconnection between entrepreneurial choices and their impact on the landscape and, at the same time, for studying the socio-cultural processes that underpin everyday entrepreneurship. In this respect, in the past decade, scholars have started to investigate the kinds of information and skills that can support farmers in their choices [4] and in so doing have placed great emphasis on the role played by technical (agronomical) knowledge and economic knowledge. Scarce attention, however, has been paid to other aspects of farmers' knowledge, for example, issues concerning identity, family, and institutions [5].

In the past decades, economic anthropologists have pointed out that entrepreneurship, like any other economic activity, is always embedded in a social and physical context and involves many individual and institutional factors [6]. This article aims to contribute to the ongoing debate by exploring the forms of knowledge (i.e., different classes of knowledge that can be identified by their distinct concepts, logical structures, and ways of judging truth and falsity) and modes of knowledge (i.e., different ways in which the subject processes the 
available information) that support farmers in their entrepreneurial choices. Specifically, it asks the following questions:

- On what grounds do farmers make their entrepreneurial choices?

- What are the modes and forms of knowledge that underpin farmers' entrepreneurial choices?

The article tackles these questions ethnographically by focusing on a case study [7] of the Monferrato area in NW Italy (Figure 1), an agricultural area that was recently recognized as a UNESCO heritage site [8]. It extends across two provinces in Piedmont, namely Alessandria and Asti, and includes about 100 municipalities [9].

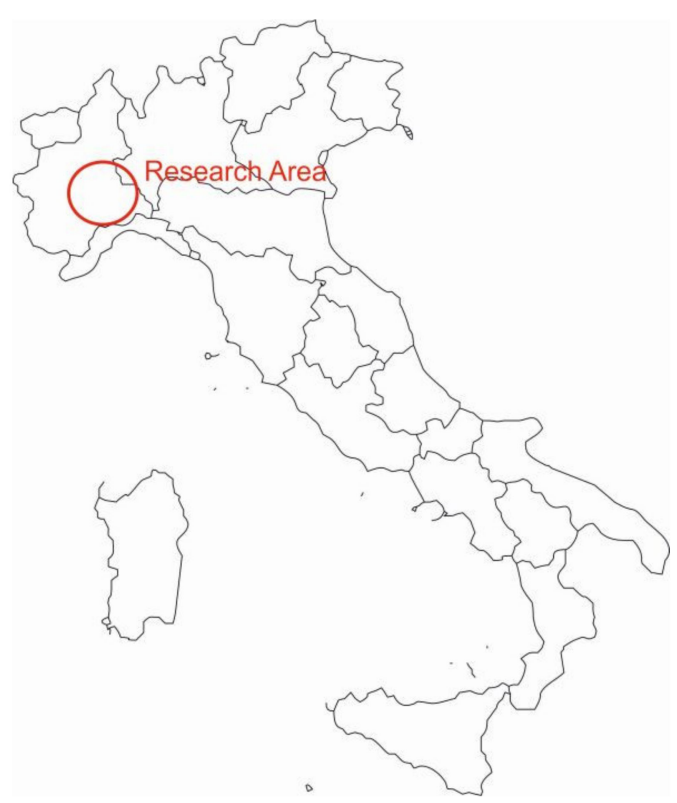

Figure 1. Localization of the research area.

Monferrato is a good example of a border area, close to metropolitan centres, such as Turin and Milan, but culturally and historically distinct and distant from them. It is a low-profile zone experiencing the same processes that affect other internal areas [10]. In particular, since the Second World War, it has faced a steady demographic decline coupled with limited industrialization [11]. While a large part of the young population left the area and moved to the nearby cities to seek a job in the manufacturing or the service industry, those who stayed and invested locally profited from agriculture. Monferrato's "restanza", the socio-cultural condition of those who had not abandoned their rural communities [12], is based on daily commuting and the development of the primary sector, which appears to be a relevant resource for the growing tourism in the area [13].

\section{Materials and Methods}

The article is part of the ongoing project "Atlante delle Filiere" (Atlas of food production chains) funded by Cariplo Foundation and conducted by the University of Gastronomic Sciences. It relies on the results of ethnographic research conducted between 2015 and 2020 in Monferrato. The research was completed in collaboration with different institutional partners, in particular Coldiretti Alessandria, the largest farmers' professional association, and some of the municipalities in the area, especially Cuccaro Monferrato, Gabiano, Lu, and San Salvatore Monferrato, which provided the logistical support and information needed for the work. Overall, the research adopted the perspective of historical ethnography [14], examining the agriculture in the area, its development, and its emplacement [15] through the lives and work of professional farmers.

Fieldwork was conducted during different campaigns that focused on specific aspects of the rural landscape: hazelnut production was investigated between 2015 and 2018, 
involving interviews with 27 producers and the observation of their farms; and cereal production was examined between 2019 and 2020 through interviews with 24 producers and observations of their farms.

The sample included small and medium-sized professional farms. Although the sample was not constructed to achieve perfect statistical representativity but rather aimed to encompass firms with more than 10 years of activity, it mirrors the overall gender distribution in this sector around $78 \%$ of Italian farms are run by male entrepreneurs. See: [16] (Del Prete et al., 2015). Interviews were conducted with 36 male farmers and 15 female farmers. While the average age of farmers in Italy is 55 years [17], the interviewees' ages ranged from early 30 s to early 80 s, with an average of 54 years.

The campaigns were structured to allow a comparative case study analysis [18]. In particular, the interviews were conducted using the same semi-structured format, which involved questions aimed at investigating different aspects of the interviewees' professional life, the business history of the farm, its production specialization, the reasons for the business configuration, the interviewees' relationships with their family and the surroundings, and the way in which these relationships influence the running of the farm. All the interviews were structured according to the life story method [19].

The information gathered from the interviews was integrated with ethnographic observation and archival research. The ethnographic observation [20] focused on the farms and was used to situate and reach a better understanding of the complexity of the farming activities as well as the material conditions of the work. Archival research was conducted to ensure a better exploration of the socio-economic dynamics of the sector and its development. In particular, it investigated the statistical materials developed by national bodies (e.g., the National Institute for Statistics, the ISTAT) and local administrations (such as the Chamber of Commerce of Alessandria and the Province of Alessandria). With this approach, the research involved the analysis of news articles appearing in local newspapers (e.g., Il Piccolo and Il Monferrato) and professional magazines (e.g., Agricoltura, published by the regional administration, and Agricoltura Alessandrina, published by Coldiretti Alessandria).

For the sake of this article, the data are elaborated into two parallel ethnographic accounts [21]. The narrative structure of the accounts helps to familiarize the reader with the specific characteristics of the ethnographic subjects through the centrality given to specific informants selected for the representativity of their experience and work. The two informants were chosen because, based on their age, gender, education, and family composition and their enterprises' characteristics (size of the company, turnout, years of activity, etc.), they appeared to be comparable (the comparison between the two cases was also made easier by their shared demographic profile as both of them were in their 50s, had over 10 years of experience in the field, were married, and were fathers) and to represent the average of the informers. They could be considered examples of that ethnographic "anyone" who is a human subject over and above proximal categorizations and identifications [22]. The choice to approach these life stories also follows the methodological model proposed by Bourdieu and his research team in their research on social suffering in the suburbs of Paris [23]. In this research, the urban condition was exposed through the life stories of people occupying different positions and social roles. The disenfranchisement of individual narrations was used as a heuristic strategy to represent and explore the complexity of the investigated phenomenon [23]. Similarly, the juxtaposition of the two farmers' life stories is chosen here to highlight the fundamental elements that mark the knowledge processes underpinning the farming decision-making process. The first one focuses on cereal producers through the experience of Paolo; the second one centres on hazelnut production, discussing the experience of Carlo. The ethnographic accounts of the two life stories present the main cultivation in the area and aim to provide comprehensive insights into the modes and forms of knowledge and the structure of the knowledge process that is involved in the entrepreneurial choices of the farmers. At the end of the paragraph, Table 1 summarizes the similarities and differences in the entrepreneurial characteristics of the two farms and their future development. 
Table 1. Comparison of the choices made by Paolo and Carlo.

\begin{tabular}{|c|c|c|}
\hline Factors & Paolo & Carlo \\
\hline Individual's work expectations & $\begin{array}{c}\text { At least } 5 \text { years before retirement } \\
\text { Continuation after retirement as a } \\
\text { part-time farmer }\end{array}$ & $\begin{array}{c}\text { At least } 7 \text { years before retirement } \\
\text { Continuation after retirement as a } \\
\text { part-time farmer }\end{array}$ \\
\hline Expected life of the enterprise & $5-20$ years & $\begin{array}{l}5-20 \text { years } \\
\text { Possibility of transgenerational } \\
\text { continuation }\end{array}$ \\
\hline Geographical characteristics & Scarcely versatile terroir & Scarcely versatile terroir \\
\hline $\begin{array}{l}\text { Economic expectation of turnover from } \\
\text { the cultivation }\end{array}$ & $\begin{array}{c}\text { EUR 40,000 / year in the condition of a } \\
\text { stiffening market }\end{array}$ & $\begin{array}{c}\text { EUR 55,000 / year in the condition of an } \\
\text { expanding market }\end{array}$ \\
\hline Perception of the future & Economic decline & Economic expansion \\
\hline Entrepreneurial choice & $\begin{array}{l}\text { De-investment } \\
\text { Avoid change }\end{array}$ & $\begin{array}{l}\text { Investment } \\
\text { Further cultivation change }\end{array}$ \\
\hline
\end{tabular}

\section{Results}

\subsection{Cereals}

Across Monferrato, it is common to find fields cultivated with wheat and corn, even on the slopes of the hills. Cereals are key for the local rural landscape and the agricultural economy, representing the backbone of most farms' business [24,25]. They are crucial, in particular, for the farms working on the vast lowland that divides the Po River from the Apennines, which is surrounded by the Monferrato hills. This area has established itself in the Piedmont imaginary as a land of cereal production, especially soft and hard wheat and corn, since the 1970s [26].

As in much of southern Piedmont, agriculture is linked to small family-owned enterprises with a strong fragmentation of properties [27,28]. Until the Second World War, each farm based its economy on the integration of farming and agriculture, with a combination of cereals, grapes, and vegetables as well as silkworms, flax, and hemp [24]. This production model disappeared in the 1950s, leading to a progressive focus on cereal farming to the detriment of other crops and livestock. Simultaneously, the mechanization of production modified the shape of the landscape. This rapid transformation turned the area into one of the main centres for the production of wheat in Italy. However, there has been only limited expansion of the hectarage of the local companies: today, a standard farm covers between 20 and 40 hectares. Paolo explained:

My farm is like many other farms you find here around. I cultivate 40 hectares of cereals, mostly wheat and corn. I live on the farm with my family, and my fields are divided between three municipalities, the farthest about $10 \mathrm{~km}$ from home. I inherited the farm from my father, and he got it from his father. I almost doubled the land we had, but every year it is becoming harder and harder, and I am not sure there is any future for us ahead. The margins are becoming smaller and smaller, the costs higher and higher. I must plant cereals. Not because I want or love them but because they are the only thing that grows decently in this harsh soil. Until 20 years ago, we planted a lot of sugar beetroot. It was quite an interesting alternative and quite profitable. However, when they closed the sugar factory in Casei Girola, we weren't able to sell the roots for a good price, so we ended up cultivating two things: wheat and corn.

The main production alternative to wheat is hybrid corn. In the early 1990s, when the price of wheat started declining [11], some of the farms specialized in intensive corn production, achieving good results. However, from the 2000s onwards, the profit from corn decreased. In 2019, it was selling at the same price as in June 2007, around EUR 170/ton (data: Borsa Merci Telematica Italiana). 
Wheat, even more than corn, has experienced a profound crisis at the national level. The price has dropped significantly in the last decade, from EUR 500/ton in 2007 to EUR 230/ton in 2019 (data: Borsa Merci Telematica Italiana). The price drop resulted in a progressive contraction of the overall production (the production in the province decreased from 300,000 tons to 100,000 tons between 1981 and 2020; data: Piedmont Region). Despite the general abandonment of this cultivation, it is still strong in the area. However, Paolo and other local farmers do not speak about wheat with pride. A sense of resignation permeates the social poiesis [29] of the farmers.

I have to work for another 5 years before being eligible for retirement. I am sure I will also be farming after retirement. Always cereals, for sure. To change, I would have to invest a lot in making new wells-we must dig wells 80 to $100 \mathrm{~m}$ deep to find water-and buy new equipment. Why should I? I would need 20-30 years to pay back the money, and I do not want to leave my son to pay my debt [Pietro has one son in his early 20s who works in Milan in the service sector and expresses no intentions to continue Paolo's job]. In such a situation, to continue with cereals is something like security. I do not need to do much investment; I know to whom I can sell my products; I can try new varieties without compromising my farm and my family economically. So, this year is corn and wheat; next year will be wheat and corn. In the end, in my situation, why change?

\subsection{Hazelnuts}

The family photo below (Figure 2) is almost 70 years old. It has been digitalized by the local museum [30]. It was taken in the early 1950s, just outside Lu. It portrays three sisters in their 20s: young wives and perhaps mothers too. Behind them, we can see the countryside where they lived and grew up. The photographer wanted to show the details of the landscape on that late summer day. The hills facing south were mostly covered by orderly vineyards, probably Barbera grapes. The lowland was cultivated with maize, still to be harvested, and forage. The few free and ploughed areas suggest that wheat was harvested in the previous months. That is what the landscape of the Piedmont hills looked like after the war had ended and normality had returned when it began negotiating its future between peasantry and industry.

The landscape in the picture is almost unrecognizable today. That is not because of the overbuilding tendencies typical of industrial development in northern Italy [31], which resulted in sad sequences of warehouses, grey buildings, and unattended gardens [32]. Rather, the change is an entirely agricultural story. The vineyards thinned out and gave way to the cultivation of new crops. Some, such as rapeseed, were alien or marginal 20 years ago. The presence of rapeseed exemplifies the impact of the European agricultural policy of incentives. Tree crops such as hazel, on the other hand, are the main countermeasure to the ever-advancing woods [33].

Hazelnut cultivation only became prominent in Monferrato in the last two decades. In the 1950s, there were about 20 hectares of hazelnut groves. Most were concentrated in the south-western part of Alessandria Province [34] and near Alba, which is the most productive crop development district in Piedmont [35]. Although institutions became interested in developing hazelnut cultivation, little was achieved, and it was mostly limited to self-consumption. However, at the end of the 1990s, it became more prominent in Monferrato, notably in $\mathrm{Lu}$, thanks to the initiative of the local cooperative Corilu Company (www.corilu.it last accessed on the 7 September 2021). The profitability of hazelnuts, about three times that of wheat (in the area, in 2018, the expected gross income per hectare for wheat cultivation was 750 euros, while for hazelnuts was 4500 euros. See: [36]), enabled them to take hold quickly in Monferrato. Between 2006 and 2015, the cultivation expanded by $515 \%$ in extension and $565 \%$ in production [36]. Carlo, an agricultural entrepreneur from Monferrato who started leading his farm in the early 2000s, explained:

The hazelnut was for all of us [farmers] like a dream and a new hope. I started with a few giornatas [the giornata is the traditional unit of measurement in 
Piedmont, equal to about a third of a hectare]. When production began, I saw that it could be an alternative solution for us. Every year I extend a piece of land. I reached 12 hectares of hazelnuts. That new piece of land is a piece of future for me and my children.
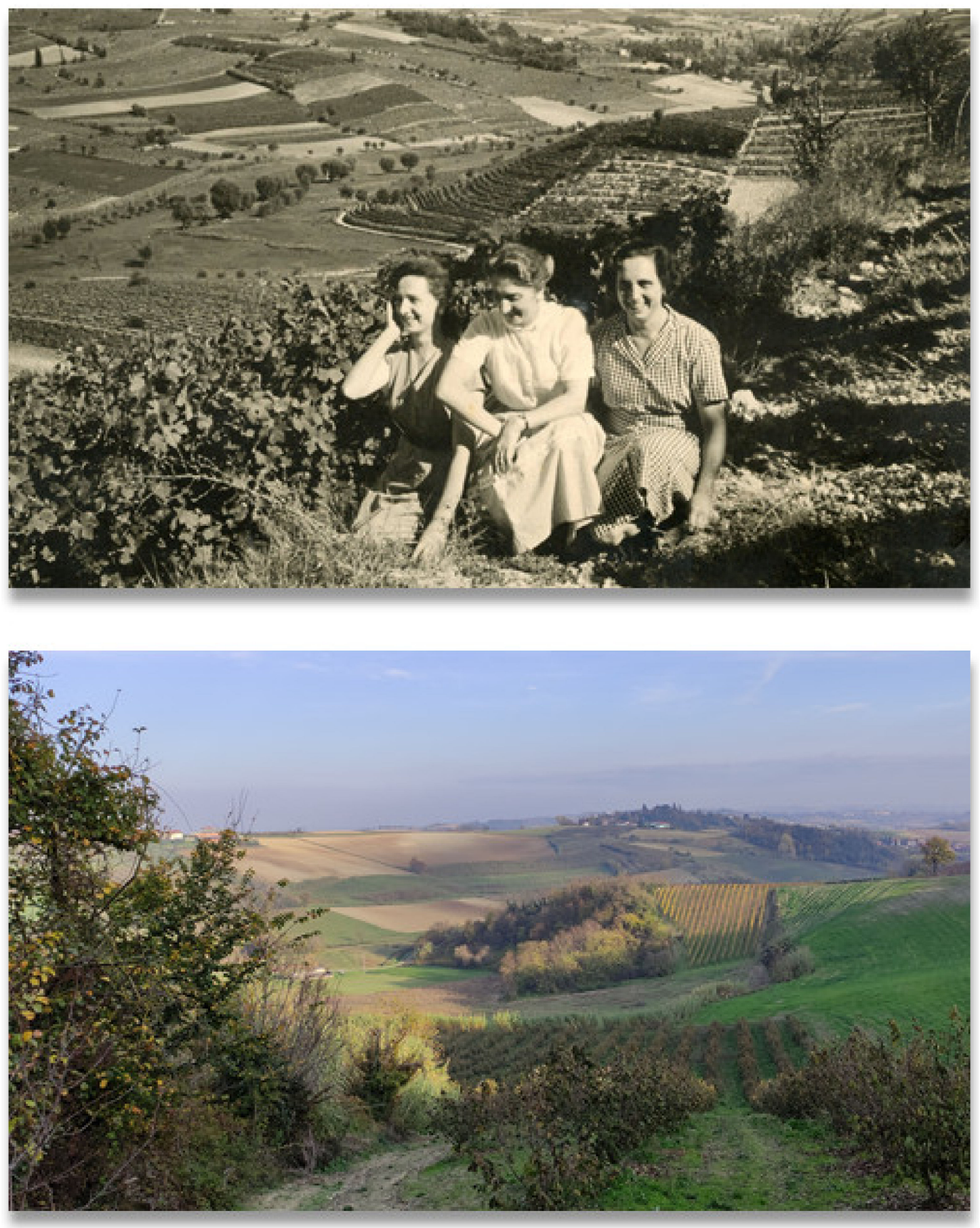

Figure 2. The Forni sisters with a view of the Braida valley (early 1950s) and the present landscape of the valley.

Carlo is 55 years old. Although his two children have not finished secondary school yet, he is already posting pictures of them in the fields, working with him on the tractor. His company is small, just over 10 hectares, plus the management of a few others. His father used most of them for the vineyard, but, in the mid-1990s, Carlo chose to abandon viticulture. 
It was yielding too little. I sold my products through the winery cooperative, but it only paid the expenses. Wheat is better, I told myself. Frankly, if I hadn't had my young children to support and I had fewer years to work until retirement ... I don't think I would have done it. I probably would have accepted to just get by until the end and then ... let the others think about it. I like to think that everything won't be finished in a few years, and I still hope that they [the children] will take up the company. However, I understood that the future is different for each of us. For those who know how to sell wine, the vine will be their future. For me, it is the hazelnut, and that is the future I intend to pursue.

In 2010, a solid supply chain agreement was established with the Elah Dufour Novi group, which has operational headquarters in Novi Ligure (AL). It was promoted by the farmers' association Coldiretti, which also favored the adoption of hazelnuts. The agreement guaranteed a market outlet for the products and a guaranteed fixed price without intermediaries. Since 2010, Elah Dufour Novi, in collaboration with the Coldiretti provincial federations of Alessandria and Asti, implemented its supply chain pact. Then, in 2016, it promoted the creation of the Monferrato Frutta cooperative for the collection and delivery of raw materials to Elah Dufour Novi. The cooperative is owned by all the hazelnut cultivators who adhere to the pact and receive payments based on their sales and the quality of the product without further intermediation costs. Then, the shelled hazelnuts are delivered to the purchasing company via a trusted service supplier. The 2016 agreement lasted for 3 years and involved 100 cultivators, 300 hectares, and at least 3000 quintals of hazelnuts per year. In 2019, the agreement was renewed until 2023 [33].

To know that all my products are, let's say, already sold without a big fuss is absolutely important. Even more, it is to know that the market wants more and more hazelnuts. It means that my land will also have value in the future and, even if my sons won't continue working on the farm, they can sell the field - this idea makes my heart ache but ... you know, better be realistic about the risks-and repay the investments I made and continue working. I am optimistic about it.

\section{Discussion}

The two ethnographic accounts present farmers envisioning and commenting on their motivation and expectation linked with their business and their cultivation choices. These encompass different processes attaining explicit and implicit knowledge. Explicit knowledge "is information with meaning which can usually be expressed verbally ... it is consciously available and it can be communicated using symbol systems like language" [37]. Thus, it is the knowledge that is overtly expressed in the accounts of the life stories. Implicit knowledge, also known as tacit knowledge [38], pertains "to what we can do without being able or even wanting to explicitly indicate how or why we do something" [37]. It refers to affects involving the individuals and their processing [39]. These two forms of knowledge are mutually integrated and underpin the decision-making process.

The farmers' choices involve first an explicit mode of knowledge that emerges through their presentation and defence of their decisions. These are taken considering different forms of knowledge. The academic debate has suggested the importance of technical and economic knowledge. The research confirms (Stewart, 2015, \#21233; Stewart, 2015, \#21233) this relevance and shows the deep and restrained integration of farming activities within the global economy [40]. However, these two forms of knowledge are not the only ones that have a role in decision making. The study suggests that four main forms of knowledge are involved:

- Environmental knowledge, which is knowledge concerning the physical and historical characteristics of the farms' locale (e.g., the type of soil, agricultural history of the place, and presence and function of infrastructures needed for the business, such as irrigation or road systems);

- Farming knowledge, which comprises the technical agricultural know-how concerning the different types of cultivation; 
- Farm knowledge, which encompasses knowledge concerning the trend of the market as well as its needs and perspectives;

- Private knowledge, which consists of emotional and factual knowledge concerning the needs and desires of the farmers and their families.

These different forms of knowledge inform the farmers and allow them to envision their future. Anthropologists have pointed out that the future is primarily a cultural construct used by communities to assess the possible outcome of their actions and expectations [41]. In this respect, the creation of the future represents a fundamental step in the knowledge process behind an entrepreneurial choice.

The farmers build their future considering four main factors:

- Individual work expectations, which are the economic and affective anticipations lying in farming;

- The expected life of the enterprise, which is the anticipated end of the farm's business life;

- Geographical characteristics, which concern the possibilities provided by the local environment and its change;

- The economic expectation of turnover from the cultivation, which is the expected income generated in the short and medium terms by cultivation.

The words of the informants, though, show a deep emotional connotation that suggests that the decision is also made on the grounds of a different, implicit mode of knowledge [37]. Emotions play a key role in entrepreneurship since they drive analyses and decisions and shape the forms of intersubjectivity underpinning the occurrence of economic activity [42-44]. Two main sentiments pervade the entrepreneurial decisions: on the one hand, resignation, and on the other hand, hope. These are opposite feelings that frame and elicit different actions, leading the farmers to diminish or intensify their investments and activity.

Thus, entrepreneurship relies on implicit and explicit knowledge. This knowledge embeds the decision-making process in the locale. On the one hand, explicit forms of knowledge generate cogent information concerning the past and present of different aspects of the locale and the business. This means that decisions are never abstract but always linked to the means, tools, and conditions of production, even when they concern the imagination of the future and create an explicit interconnection between entrepreneurship and locale. Implicit knowledge also contributes to furthering the embeddedness. In fact, emotions are not just inner psychological reactions to the environment. Rather, they: "are not properties of subjects or objects, but work, through their circulation between subjects and objects, to assign affective value. Much like monetary value becomes attached to commodities in a capitalist economy, in affective economies, over time, feelings and emotions become 'stuck' to particular subjects, objects, or spaces such as the rural. This allows them to "align individuals with communities—or bodily space with social spacethrough the very intensity of their attachments" [45].

Emotions are thus part of the surroundings, an affective landscape [46] that the farmers live in, relate to, and take inspiration from for their farming activity. Therefore, implicit and explicit knowledge contribute to making entrepreneurship deeply situated [47], never divorceable from the specificity of the locale, and only understandable in the light of the dynamics that characterize local communities and their knowledge.

\section{Conclusions}

The article answered two crucial questions about the socio-cultural foundation of farming entrepreneurship: On which grounds do farmers make their entrepreneurial choices, and what are the modes and forms of knowledge that underpin farmers' entrepreneurial choices? Through the exploration of the ethnographic case study of Monferrato farmers, it showed that entrepreneurial choices are based on explicit and implicit knowledge, encompassing forms of knowledge linked to the environment in which they live, their trade, the characteristics of their firms, issues concerning their family and private life, and the 
emotions linked with the surroundings. All these types of knowledge inform the farmers' envisioning of their future and guide them in their choices in terms of investments and crop selection.

Through this approach, the article aimed to set aside a common leitmotif that has pervaded the debate about entrepreneurial farming, particularly in the case of small and medium-sized farms. This motif presents farmers as undefended subjects of global forces that govern their entrepreneurial development and the transformation of the local landscape. The research suggests, instead, the centrality of the individual farmers' agency. Although economic trends represent an important constraint for farmers, it is through a process of knowledge (and not a mere execution of external input) that farmers make their choices and therefore build the rural landscape. Entrepreneurship thus develops in relation to the specificities of the local reality, and these specificities, as well as the knowledge of the farmers, influence their choices, eliciting abandonment or reactivation. Thus, the article closes by asking new questions concerning how to strengthen the local knowledge process and suggesting the need to support local farmers with alternative and new information and knowledge to expand their possibilities and empower their agency.

Funding: This research did not receive external funding.

Institutional Review Board Statement: The study was conducted according to the guidelines of the Declaration of Helsinki and approved by the Ethics Committee of the University of Gastronomic Sciences (protocol code 5/2020, 4 December 2020). The research was conducted according to the ethical guidelines of the American Anthropological Association (Principles of Professional Responsibility). In this article, the names of the research participants, their sensitive data, as well as the names of places have been anonymized.

Informed Consent Statement: Informed consent was obtained from all subjects involved in the study.

Data Availability Statement: Data are contained within the article.

Acknowledgments: I thank Coldiretti Alessandria, the administrations of the municipalities belonging to the Inter-municipal Technical Committee on Hazelnut Cultivation promoted by the municipality of Lu and the municipality of Gabiano, and the companies and farmers who took part in the research.

Conflicts of Interest: The author declares no conflict of interest.

\section{References}

1. Sereni, E. History of the Italian Agricultural Landscape; Princeton University Press: Princeton, NJ, USA, 1997.

2. Rebora, G. La Civiltà della Forchetta; Laterza: Roma/Bari, Italy, 1998.

3. Montanari, M. Italian Identity in the Kitchen, or, Food and the Nation; Columbia University Press: New York, NY, USA, 2013; 106p.

4. Dias, C.S.L.; Rodrigues, R.G.; Ferreira, J.J. Agricultural entrepreneurship: Going back to the basics. J. Rural Stud. 2019, 70, 125-138. [CrossRef]

5. Fitz-Koch, S.; Nordqvist, M.; Carter, S.; Hunter, E. Entrepreneurship in the Agricultural Sector: A Literature Review and Future Research Opportunities. Entrep. Theory Pract. 2017, 42, 129-166. [CrossRef]

6. Rosa, P.; Caulkins, D.D. Entrepreneurship Studies. In A Companion to Organizational Anthropology; Caulkins, D.D., Jordan, A.T., Eds.; Wiley-Blackwell: Chichester, UK, 2013; pp. 98-121. [CrossRef]

7. Yin, R.K. Case Study Research and Applications: Design and Methods, 6th ed.; Sage: Thousand Oaks, CA, USA, 2018.

8. 38th World Heritage Committee. Advisory Body Evaluation: The Vineyard Landscape of Piemonte: Langhe-Roero and Monferrato (Italy); United Nations Educational, Scientific, and Cultural Organization: Doha, Qatar, 2014.

9. Fontefrancesco, M.F. Food Festivals and Local Development in Italy: A Viewpoint from Economic Anthropology; Palgrave: London, UK, 2020.

10. Riabitare l'Italia. Le Aree Interne tra Abbandoni e Riconquiste; De Rossi, A., Ed.; Donzelli: Roma, Italy, 2018.

11. Castronovo, V. (Ed.) L'economia Alessandrina dal Secondo dopo Guerra ad Oggi; Cassa di Risparmio di Alessandria: Alessandria, Italy, 1992.

12. Teti, V. Pietre di Pane: Un'antropologia del Restare, 1st ed.; Quodlibet: Macerata, Italy, 2011; 188p.

13. Fontefrancesco, M.F. Il futuro dei Comuni minori. Etnografia di una trasformazione in corso. Dada Riv. Antropol. Post-Glob. 2015, 5, 161-178.

14. Viazzo, P.P. Introduzione All'antropologia Storica, 5th ed.; Laterza: Bari/Roma, Italy, 2012. 
15. Pink, S. From embodiment to emplacement: Re-thinking competing bodies, senses and spatialities. Sport Educ. Soc. 2011, 16, 343-355. [CrossRef]

16. Del Prete, A.; Zumpano, C. Le donne in agricoltura. Annuario Dell'agricoltura Italiana 2015. 2016, 69, 1-8.

17. Cagliero, R.; Novelli, S. Giovani e senilizzazione nel Censimento dell'agricoltura. Agrireigonieuropa 2012, 8, 1-10.

18. Eisenhardt, K.M. Building Theories from Case Study Research. Acad. Manag. Rev. 1989, 14, 532-550. [CrossRef]

19. Atkinson, R. The life story interview. In Handbook of Interview Research; Gubrium, J.F., Holstein, J.A., Eds.; Sage Publications: Thousand Oaks, CA, USA; London, UK, 2002; pp. 121-140.

20. Hobbs, D. Ethnography. In The SAGE Dictionary of Social Research Methods; Jupp, V., Ed.; Sage: London, UK, 2006 ; pp. 101-103.

21. Van Maanen, J. Tales of the Field: On Writing Ethnography; University of Chicago Press: Chicago, IL, USA, 1988.

22. Rapport, N. Anyone: The Cosmopolitan Subject of Anthropology; Berghahn Books: New York, NY, USA, 2012.

23. Bourdieu, P. The Weight of the World; Polity Press: Cambridge, UK, 1999.

24. Caramellino, A. L'archiettura rurale alessandrina. In L'architettura Ruale in Provincia di Alessandria; Caramellino, A., Ed.; Provincia di Alessandria: Alessandria, Italy, 1999; pp. 64-89.

25. Castronovo, V. (Ed.) Monferrato: Lo Scenario del Novecento; Cassa di Risparmio di Alessandria: Alessandria, Italy, 2007.

26. Forte, F. L'Agricoltura. In Strutture ed Eventi Dell'economia Alessandrina; Eco, U., Beltrame, C., Forte, F., Eds.; La Pietra: Milano, Italy, 1981; pp. 127-139.

27. Guaschino, M.; Martinotti, M. (Eds.) Contadini di Collina: Viticoltura e Condizioni Materiali Nella Cultura Orale del Basso Monferrato Casalese; Regione Piemonte Assessorato all'Agricoltura e Foreste: Torino, Italy, 1984.

28. Canobbio, S.; Telmon, T. (Eds.) Il Piemonte dei Contadini 1921-1932: Rappresentazioni del Mondo Rurale Subalpino Nelle Fotografie del Grande Ricercatore Svizzero/Paul Scheuermeier; Priuli \& Verlucca: Ivrea, Italy, 2007.

29. Herzfeld, M. Cultural Intimacy: Social Poetics in the Nation-State; Routledge: New York, NY, USA; London, UK, 1997.

30. Fontefrancesco, M.F. The making of a community: The making of a photo collection in a rural community in Italy. Issues Ethnol. Anthropol. 2014, 9, 885-894. [CrossRef]

31. Turri, E. La Megalopoli Padana, 2nd ed.; Marsilio: Venezia, Italy, 2004.

32. Trevisan, V. Tristissimi Giardini; Edizioni Laterza: Bari/Roma, Italy, 2010.

33. Fontefrancesco, M.F.; Balduzzi, G. Speranza e vocazione produttiva: Sviluppo corilicolo e marginalizzazione rurale in Monferrato. Ratio Sociol. 2018, 11, 97-120.

34. Romisondo, P. La coltura del nocciuolo in Piemonte. In La Coltura e il Mercato del Nocciolo. Studi e Indicazioni; Amministrazione Provinciale di Alessandria, Ed.; Centro Documentazione e Ricerche Economiche e Sociali della Provincia di Alessandria: Alessandria, Italy, 1968; pp. 83-94.

35. Garnero, G.; Godone, D.; Garbarino, M.; Godone, F. Evoluzione del paesaggio delle Langhe: L'espanzione del noccioleto. Ann. Del Tur. 2012, 1, 139-150.

36. Pansecchi, A. Nocciola: Sviluppo Agricolo e Prospettive Economiche per il Territorio. In Pecetto di Valenza: Tavolo Tecnico Intercomunale sulla Corilicoltura; Comune di Pecetto di Valenza: Alessandria, Italy, 2018.

37. Pöppel, E.; Bao, Y. Three Modes of Knowledge as Basis for Intercultural Cognition and Communication: A Theoretical Perspective. In Culture and Neural Frames of Cognition and Communication; Han, S., Pöppel, E., Eds.; Springer: Berlin, Germany, 2011 ; pp. $215-231$. [CrossRef]

38. Hau, Y.S.; Kim, B.; Lee, H.; Kim, Y.-G. The effects of individual motivations and social capital on employees' tacit and explicit knowledge sharing intentions. Int. J. Inf. Manag. 2013, 33, 356-366. [CrossRef]

39. Stewart, K.; Lewis, E. Affect and Emotion, Anthropology of. In International Encyclopedia of the Social E Behavioral Sciences, 2nd ed.; Wright, J.D., Ed.; Elsevier: Oxford, UK, 2015; pp. 236-240. [CrossRef]

40. Van der Ploeg, J.D. The New Peasantries: Rural Development in Times of Globalization, 2nd ed.; Routledge: London, UK, 2018.

41. Bryant, R.; Knight, D.M. The Anthropology of the Future; Cambridge University Press: Cambridge, UK, 2019.

42. Baron, R.A. The Role of Affect in the Entrepreneurial Process. Acad. Manag. Rev. 2008, 33, 328-340. [CrossRef]

43. Grichnik, D.; Smeja, A.; Welpe, I. The Importance of Being Emotional: How do Emotions Affect Entrepreneurial Opportunity Evaluation and Exploitation? J. Econ. Behav. Organ. 2010, 76, 15. [CrossRef]

44. Richard, A.; Rudnyckyj, D. Economies of Affect. J. R. Anthropol. Inst. 2009, 15, 57-77. [CrossRef]

45. Peeren, E. The affective economies and political force of rural wildness. Landsc. Res. 2019, 44, 834-845. [CrossRef]

46. Tuan, Y.-F. Romantic Geography: In Search of the Sublime Landscape; University of Wisconsin Press: Madison, WI, USA, 2013.

47. Lauer, M.; Aswani, S. Indigenous Ecological Knowledge as Situated Practices: Understanding Fishers' Knowledge in the Western Solomon Islands. Am. Anthropol. 2009, 111, 317-329. [CrossRef] 